\title{
ŁACINNICZKA NA TRONIE XIII-WIECZNEJ SERBII. WIZERUNEK KRÓLOWEJ JELENY Z ANDEGAWENÓW W PISMACH ARCYBISKUPA DANILA II
}

\author{
ZOFIA BRZOZOWSKA
}

\begin{abstract}
Zofia Brzozowska, Lacinniczka na tronie XIII-wiecznej Serbii. Wizerunek królowej Jeleny $z$ Andegawenów w pismach arcybiskupa Danila II (The Latin Queen on the Throne of 13th century Serbia. The Image of Helene d'Anjou in the Writings of Archbishop Danilo II).
\end{abstract}

Balcanica Posnaniensia. Acta et studia, XIX, Poznań 2012, Wydawnictwo Instytutu Historii UAM, pp. 71-83, ISBN 978-83-63-047-17-7, ISSN 0239-4278. Polish text with a summary in English.

Zofia Brzozowska, Uniwersytet Łódzki, Instytut Historii, Katedra Historii Bizancjum, ul. Aleksandra Kamińskiego 27a, 90-219 Łódź, Polska - Poland.

Jelena Andegaweńska, żona króla Stefana Urosza I (1243-1276), a jednocześnie matka dwóch władców: Stefana Dragutina (1276-1282) i Stefana Urosza II Milutina (1282-1321), jest z całą pewnością postacią ponadprzeciętną ${ }^{1}$. We współczesnej literaturze przedmiotu spotkać można nawet głosy, iż mamy w jej osobie do czynienia z najbardziej wpływową kobietą na serbskiej scenie politycznej w XIII w. ${ }^{2}$

Wskutek wyjątkowego zbiegu okoliczności do naszych czasów dochowało się wiele malarskich wyobrażeń tej władczyni. Za najwcześniejsze z nich możemy uznać wizerunek, pochodzący z portretu zbiorowego rodziny panującej, towarzyszącego scenie śmierci Anny Dandolo - matki Urosza I, a tym samym teściowej bohaterki niniejszego szkicu. Przedstawienie to wykonano w technice fresku na ścianie monasteru w Sopocianach w latach 1263-1268³. Dość statyczną sylwetkę Jeleny, odzianej w bogate, purpurowo-złote szaty, królewską koronę i biżuterię umiejscowiono tuż za plecami jej nachylonego nad katafalkiem matki małżonka, pomiędzy postaciami sy-

\footnotetext{
${ }^{1}$ А. Веселиновић, Р. Љушић, Српске династије, Београд 2008, s. 54-56.

2 C. Hawhesworth, Voices in The Shadows. Women and Verbal Art in Serbia and Bosnia, Budapest 2000 , s. 68.

${ }^{3}$ В. Ј. Ђурић, Историјске композииије у српском сликарству Средњега Века и њихове књижевне паралеле, „Зборник радова Византолошког института”, vol. 11 (1968), s. 104-105.
} 
nów. Portret monarchini jest dość dobrze zachowany i ukazuje relatywnie młodą osobę o szczupłej twarzy, jasnej cerze i ciemnobrązowych włosach ${ }^{4}$.

Co więcej, Andegawenka pojawia się również - obok swego męża i synów na wielu kompozycjach fundacyjnych, zdobiących wnętrza świątyń wznoszonych w Serbii na przełomie XIII i XIV w. ${ }^{5}$ We wspomnianych Sopocianach jej przedstawienie odnajdujemy w narteksie cerkwi ${ }^{6}$, w monasterze Gradac (ok. 1275 r.) ukazano ją - w bogatych, monarszych szatach i otwartej (królewskiej) koronie na głowie ${ }^{7}-$ wraz z małżonkiem, w zaszczytnym towarzystwie Chrystusa, Bogurodzicy i Stefana Nemanji ${ }^{8}$.

Na fresku zdobiącym kaplicę monasteru Djurdjevi Stupovi, wzniesioną w latach 1283-1285 przez Stefana Dragutina w miejscowości Ras, jej postać wpleciona została w rozbudowaną kompozycję, ukazującą wielu wybitnych Nemaniczów, od świętego protoplasty rodu i Stefana Pierwoukoronowanego poczynając, jako mnichów adorujących Syna Bożego. Interesujące, że Jelena - w przeciwieństwie do męskich przedstawicieli dynastii - przedstawiona tu została w odzieniu świeckim: skromnej wdowiej sukni i białej chuście szczelnie zakrywającej włosy. Rezygnując z wyposażenia wizerunku władczyni w monarsze insygnia, średniowieczny artysta postanowił oddać jej cześć w zgoła inny, całkowicie zgodny z założeniami sztuki bizantyńskiej, sposób - poprzez umieszczenie koło jej portretu napisu: „wielka królowa” (велика кралица) $)^{9}$. Podobną inskrypcję (Елена кралица вьсе срьпьске земле) odnajdujemy obok wyobrażenia Andegawenki, pochodzącego z cerkwi w Arilje, wykonanego w 1295-1296 r., ukazującego ją nota bene, w nawiązaniu do typowo serbskiej tradycji ikonograficznej, w monastycznym habicie ${ }^{10}$. Jako mniszkę wyobrażono bohaterkę niniejszego artykułu również na fresku w Gračanicy (1319-1321), lokując jej sylwetkę obok postaci męża oraz wizerunku Stefana Milutina i księcia Konstantyna, odbierających - znów na modłę wschodniorzymską - błogosławieństwo z rąk Chrystusa Emmanuela, przedstawionego półpostaciowo tuż nad ich głowami ${ }^{11}$.

Zupełnie wyjątkowe miejsce w tej swoistej galerii portretów królowej Jeleny zajmuje natomiast dość spora $(72,5$ X $51 \mathrm{~cm})$ ikona wielopostaciowa, wykonana najprawdopodobniej na zlecenie Andegawenki przez serbskiego lub greckiego artystę na przełomie XIII i XIV stulecia i ofiarowana przez nią papieżowi Bonifacemu VIII. Warto zatrzymać się nieco dłużej przy tym zabytku, gdyż - jak wskazuje na to już

${ }^{4}$ А. Веселиновић, Р. Љушић, op. cit., tabl. 40. Wypada również w tym miejscu nadmienić, iż wśród badaczy brak jest jednomyślności w kwestii identyfikacji poszczególnych osób przedstawionych na omawianym fresku - część historyków sztuki pragnie widzieć Jelenę w osobie młodej niewiasty, całującej zmarłą w rękę, umiejscowionej w lewym dolnym rogu kompozycji. В. J. Ђурић, op. cit., s. 105-106.

${ }^{5}$ B. Todić, Serbian Medieval Painting. The Age of King Milutin, Belgrade 1999, s. 8, 22.

${ }^{6}$ Ibidem, s. 46.

7 Ж. Фејфрић, А тело јој нађоше да лежи као у роси, „Српско наслеђе. Историјске свеске”, 1998, № 10.

\footnotetext{
${ }^{8}$ B. Todić, op. cit., s. 39.

${ }^{9}$ Ibidem, s. 40, 293-294.

10 Ibidem, s. 40-41, 297-299.

11 Ibidem, s. 50-51, 334.
} 
osoba obdarowanego - ukazuje on doskonale specyfikę kultury XIII-wiecznej monarchii Nemaniczów, zawieszonej niejako między bizantyńskim Wschodem, a łacińskim Zachodem Europy. Antycypując pewne fakty możemy też zaznaczyć, że omawiane przedstawienie, wykonane jako dar dla zwierzchnika Kościoła katolickiego, mówi nam również wiele o światopoglądzie samej Jeleny.

Kompozycja interesującej nas tu ikony składa się z dwóch kwater. Na wyższej z nich odnajdujemy wyobrażenie apostołów - Piotra i Pawła, czczonych głównie przez chrześcijaństwo zachodnie. Sposób wymodelowania postaci, misterny rysunek szat oraz umieszczenie ponad głowami świętych figury Chrystusa błogosławiącego, zdradzają silne wpływy sztuki bizantyńskiej. Niższa część przedstawienia zawiera z kolei sylwetki donatorów - Stefana Milutina i Dragutina, ukazanych w pozycji orantów. Między nimi natomiast znajduje się wizerunek ich matki: odzianej w mnisi habit, przyjmującej w kornej postawie błogosławieństwo od niezidentyfikowanego świętego, wyobrażonego w szatach katolickiego biskupa ${ }^{12}$. Jak więc widać, mamy tu do czynienia z przedstawieniem niezwykle synkretycznym, na którym za pomocą bizantyńskich środków wyrazu usiłowano oddać treści zgoła odmienne - przywiązanie serbskiej władczyni do obrządku łacińskiego oraz jej lojalność względem Stolicy Apostolskiej. Co ciekawe, według znawców przedmiotu, na życzenie bohaterki niniejszego szkicu miało powstać jeszcze jedno tego typu przedstawienie, ofiarowane kościołowi św. Mikołaja w Bari ${ }^{13}$ (nie zachowało się niestety do naszych czasów, o jego istnieniu informują nas jedynie źródła XVII-wieczne) $)^{14}$.

\section{Katolicka królowa i prawosławna święta - szkic do portretu}

Szczegółowe odtworzenie biografii interesującej nas tu władczyni wykracza poza ramy niniejszego tekstu. Co więcej, biorąc pod uwagę skąpą ilość i niejednoznaczność przekazów źródłowych można założyć, iż tego typu rekonstrukcja jest zadaniem zgoła niewykonalnym. Warto jednak przywołać kilka faktów z życia Jeleny Andegaweńskiej, zwłaszcza, że wiele $z$ nich przemawiałoby raczej przeciw zaliczeniu jej w poczet świętych Serbskiej Cerkwi Prawosławnej, czy też - przyznaniu w nowożytnej historiografii rangi postaci o pierwszorzędnym znaczeniu dla dziejów monarchii Nemaniczów.

I tak kwestią, której nie sposób nie zauważyć, jest przede wszystkim cudzoziemskie pochodzenie Jeleny - tradycja dynastyczna władców serbskich, a w ślad za nią konwencja dziejopisarska nadała jej wszak przydomek Andegaweńska (Анжујска), nieuchronnie nasuwający skojarzenia $\mathrm{z}$ francuskim domem panującym. Istotnie, we współczesnej literaturze przedmiotu spotkać można hipotezy, zakładające, że żona Stefana Urosza I była córką Raula de Courtenay, spokrewnionego zarówno z łaciń-

\footnotetext{
12 Ibidem, s. 37-39, 206-207, 295-296.

13 М. Кашанин, Српска књижевност у Средњем Веку, Београд 2002, s. 28.

${ }^{14}$ B. Todić, op. cit., s. 37.
} 
skimi cesarzami Konstantynopola, jak i królem Francji Ludwikiem IX oraz jego ambitnym młodszym bratem, jednym z ,głównych rozgrywających“ na bałkańskiej scenie politycznej w połowie XIII w. - Karolem Andegaweńskim, władcą Sycylii i Neapolu ${ }^{15}$. Interesujące, że przypuszczenie to opiera się na źródłach innej niż staroserbska proweniencji, a mianowicie - listach tego ostatniego monarchy do Jeleny, w których nazywa ją nieodmiennie swoją ,drogą krewniaczką" "16.

$\mathrm{Z}$ zachodnioeuropejskim pochodzeniem wiąże się kolejny istotny element - żona Urosza I była katoliczka, tj. używając pojęć rozpowszechnionych w XIII-wiecznej Serbii - „łacinniczką“. Co więcej, nigdy nie ukrywała swej przynależności konfesyjnej, prowadząc przez nieomal całe życie świadomą politykę religijna, mającą na celu wzmocnienie wpływów obrządku zachodniego na terytorium monarchii Nemaniczów. Świadczyć o tym może m.in.

- szeroko zakrojona działalność fundacyjna (z inicjatywy Jeleny powstały katolickie klasztory w Barze, Skadrze, Ulcinie i Kotorze, oddane do użytku ok. 1288 r. $)^{17}$;

- ożywione kontakty dyplomatyczne z papiestwem, świadectwem których jest chociażby omówiona wyżej ikona z przedstawieniem św. św. Piotra i Pawła ${ }^{18}$;

- wieloletnie poparcie, udzielane katolickiemu arcybiskupstwu w Barze ${ }^{19}$;

- aktywne wspieranie chrześcijaństwa zachodniego na obszarze oddanym w jej samodzielne władanie w 1276 r. (Zeta oraz wybrzeże Morza Adriatyckiego) ${ }^{20}$.

W tym miejscu warto jednak zaznaczyć, że przywiązanie do obrządku łacińskiego nie było w przypadku bohaterki niniejszego szkicu równoznaczne z wrogością czy też niechęcią do rytu bizantyńskiego. Wprost przeciwnie - z zachowanych źródeł wynika, że Jelena wspierała również budowę i renowację prawosławnych świątyń, najokazalszą z których - wzniesiony ok. 1270 r. monaster Gradac - obrała za miejsce swego wiecznego spoczynku (задужбина) ${ }^{21}$. Niemniej znamienny wydaje się fakt złożenia przez Andegawenkę pod koniec życia ślubów zakonnych według obrządku wschodniego. Biorąc pod uwage przytoczone powyżej argumenty, jak i niezwykły szacunek, jakim miała się cieszyć u wszystkich swych poddanych bez względu na

\footnotetext{
15 Ж. Фејфрић, op. cit.; С. Hawhesworth, op. cit., s. 67-68; А. Веселиновић, Р. Љушић, op. cit., s. 54.

16 Ж. Фејфрић, op. cit.; А. Веселиновић, Р. Љушић, op. cit., s. 54. Zagadnieniem wykraczającym poza ramy niniejszego artykułu, niemniej jednak godnym odnotowania ze względu na polskiego Czytelnika, jest kwestia pokrewieństwa Jeleny Andegaweńskiej z królową Polski Jadwigą. W świetle najnowszych ustaleń genealogicznych można stwierdzić, iż obie władczynie łączyła zarówno przynależność do jednego rodu, jak i pokrewieństwo w linii żeńskiej: córka Stefana Dragutina, Elżbieta, wydana za bana Bośni Stefana Kotromana, była babką Elżbiety Bośniaczki, matki polskiej królowej. Jadwiga byłaby więc pra-pra-prawnuczką Jeleny. http://genealogics.org/descend.php?personID =I00165016\&tree=LEO [dostęp z 7 X 2010].

17 Ж. Фејфрић, ор. cit.; С. Живковић, Варала краља са обичним Франиузом, „Српско наслеђе. Историјске свеске”, 1998, № 5 .

${ }^{18}$ C. Hawhesworth, op. cit., s. 69.

19 Ж. Фејфрић, op. cit.

${ }^{20}$ B. Todić, op. cit., s. 10-11, 33, 49.

${ }^{21}$ Ж. Фејфрић, оp. cit.; А. Веселиновић, Р. Љушић, op. cit., s. 54.
} 
wyznanie, można stwierdzić, że cechowała ją raczej postawa, którą dziś określilibyśmy mianem ekumenicznej22 (można dywagować, w jakim stopniu osobiste przekonania Andegawenki splatały się z ówczesnym klimatem polityczno-religijnym, związanym z zawartą w 1274 r. na soborze w Lyonie, między papieżem Grzegorzem X i przedstawicielami cesarza bizantyńskiego Michała VIII Paleologa, unią kościelną).

O wiele trudniej poddać jednoznacznej ocenie postawę tej królowej wobec państwa serbskiego. Z przekazów źródłowych wynika, że podczas wojny, którą Stefan Urosz I prowadził z Dubrownikiem w latach 1265-1266, uprzedzała władze adriatyckiej republiki o decyzjach swego męża ${ }^{23}$. Poczynania tego typu rozpatrywać można nawet w kategoriach zdrady stanu. Równie kontrowersyjną kwestią zdaje się być udzielenie przez Andegawenkę w 1276 r. poparcia Stefanowi Dragutinowi $\mathrm{w}$ przewrocie, mającym na celu zrzucenie $\mathrm{z}$ tronu Urosza I, w zamian za realną korzyść polityczną - otrzymanie od syna odrębnej dzielnicy (Zeta) do samodzielnego władania ${ }^{24}$.

Jakiekolwiek „rysy” odnajdowalibyśmy współcześnie na portrecie Jeleny w aspekcie moralnym i politycznym, nie możemy podważyć jednego faktu - władczyni ta już w kilka lat po swej śmierci (która nastąpiła w dniu 8 II 1314 r.) ${ }^{25}$ była obiektem oficjalnego kultu cerkiewnego. Rodzi się zatem pytanie, jakie czynniki zadecydowały o tak wczesnym wyniesieniu na ołtarze osoby, której kanonizacja zdawałaby się nam dziś posunięciem dość kontrowersyjnym. W literaturze przedmiotu zetknąć się można z tezą, iż uznanie Jeleny za świętą było elementem gry politycznej, prowadzonej przez ówczesnego zwierzchnika Cerkwi w monarchii Nemaniczów - arcybiskupa Danila II (ok. 1270-1337). Ustanawiając już ok. 1317 r. państwowy kult małżonki Urosza I chciał on najprawdopodobniej uprzedzić podobne posunięcie Stolicy Apostolskiej, a tym samym - zneutralizować potencjalne zagrożenie, wynikające dla bałkańskiego prawosławia z faktu zaliczenia królowej Serbii w poczet katolickich świętych ${ }^{26}$.

Arcybiskup Danilo II jest również tą osobą, której Jelena zawdzięcza swe poczesne miejsce w literaturze staroserbskiej. Istotnie, dostojnik ten wykreował jej barwny literacki wizerunek, nie zawahawszy się - jako pierwszy, a zapewne również jedyny twórca serbskiego średniowiecza - poświęcić osobnego utworu kobiecie ${ }^{27}$. Warto zatrzymać się na chwilę przy tej postaci, gdyż nawet pobieżny wgląd w jej biogra-

22 С. Живковић, op. cit..

23 Ж. Фејфрић, op. cit.; C. Hawhesworth, op. cit., s. 70.

24 Ж. Фејфрић, op. cit. .

25 Ж. Фејфрић, оp. cit.; А. Веселиновић, Р. Љушић, op. cit., s. 54.

26 D. Gil, Prawosławie. Historia. Naród. Miejsce kultury duchowej w serbskiej tradycji $i$ współczesności, Kraków 2005, s. 60.

27 М. Кашанин, op. cit., s. 186; Стара српска књижевност, ed. С. Томин, Сремски Карловци - Нови Сад 2001, с. 26. Jelena jest również jedyną władczynią południowosłowiańską, której poświęcono odrębny utwór literacki. Н. Гагова, Владетели и книги. Участието на южнославянския владетел в производството и употребата на книги през Средновековието (IX-XV в.): рецепцията на византийския модел, София 2010, s. 192. 
fię umożliwi nam pełniejsze zrozumienie wielu elementów, dostrzegalnych w treści i budowie formalnej zabytków, którymi będziemy się zajmować w dalszej części niniejszego artykułu.

Danilo przyszedł na świat w możnowładczej rodzinie i już jako młody człowiek miał możliwość zaznajomić się z kulturalno-politycznym klimatem monarchii Nemaniczów, przebywając na dworze króla Stefana Milutina. Po kilku latach przyjął święcenia zakonne i został oddelegowany jako prezbiter do siedziby arcybiskupa serbskiego Jevstatija II w Peciu. Etap „dworskiej edukacji” zakończył ostatecznie w 1306 r. udając się na górę Athos, gdzie rychło wybrano go ihumenem monasteru Chilandar. Pobyt (z przerwami, związanymi z pełnieniem innych wysokich stanowisk kościelnych: 1311-1315 - biskupa bańskiego, 1317-1322 - biskupa humskiego) w jednym z najświętszych miejsc prawosławia, będącym jednocześnie prężnym ośrodkiem kultury i nauki, umożliwił mu zapewne uzupełnienie wykształcenia i dogłębne zaznajomienie się ze zdobyczami cywilizacji bizantyńskiej. 14 IX $1324 \mathrm{r}$. Danilo został natomiast wybrany na zwierzchnika Serbskiej Cerkwi Prawosławnej, którą to funkcję pełnił nieprzerwanie aż do swej śmierci 19 XII $1337 \mathrm{r}^{28}$

Dla naszych rozważań szczególne znaczenie mają zwłaszcza dwa aspekty: formacja intelektualna wspomnianego dostojnika, dająca się jednoznacznie skojarzyć z tradycją Slavia Orthodoxa (znajdująca swe odzwierciedlenie w jego twórczości, zdradzającej silne powiązania z piśmiennictwem bizantyńskim $)^{29}$ oraz bliskie związki z serbskim dworem monarszym, pociągające za sobą możliwość bezpośredniego i dość bliskiego zapoznania się z postaciami, które w przyszłości opiewać będzie Danilo jako hagiograf. Warto podkreślić ten ostatni fakt: arcybiskup był współczesnym Jeleny Andegaweńskiej, znał ją osobiście, często przebywał w jej towarzystwie, a podczas pobytów na górze Athos prowadził z królową ożywioną korespondencję. Relacja ta stwarza wprost wymarzoną sytuację dla historyka: opowieść Danila o życiu Jeleny będzie w przeważającej mierze przekazem bezpośrednim, relacją ,„z pierwszej ręki”.

Jak wspomniano wyżej, Danilo II jest autorem Żywotu królowej Jeleny (Жumuje краљице Јелене) - obszernego zabytku hagiograficznego, spisanego najprawdopodobniej ok. 1317 r. w związku z oficjalną kanonizacją Andegawenki ${ }^{30}$. Co więcej, władczyni pojawia się również na kartach kilku innych utworów pióra arcybiskupa, włączonych po jego śmierci, tj. w latach 1337-1340, przez anonimowego ucznia, w skład słynnego zbornika, znanego w literaturze przedmiotu jako Żywoty królów i arcybiskupów serbskich (Житија краљева и архиепископа српских) ${ }^{31}$. Јеј роstać odnajdujemy w Żywocie króla Urosza, Żywocie św. Stefana Dragutina, Żywocie św. Stefana Milutina oraz w Żywocie arcybiskupa Joanikija.

${ }^{28}$ М. Кашанин, op. cit., s. 177-178.

29 Ibidem, s. 181.

${ }^{30}$ D. Gil, op. cit., s. 60; М. Кашанин, op. cit., s. 183; Стара српска књижевност..., s. 26; B. Todić, op. cit., s. 12.

${ }^{31}$ Dar stowa. Ze starej literatury serbskiej, ed. A. Naumow, Łódź 1983, s. 234; М. Кашанин, op. cit., s. 183-184. 
Dla pełni obrazu należy także nadmienić, że osoba Jeleny Andegaweńskiej wspominana jest również $w$ dwóch zabytkach hymnografii staroserbskiej, łączonych z imieniem patriarchy Danila III (ok. 1350-1396/9): słowie pochwalnym (помен) i służbie, skomponowanych na cześć króla Stefana Milutina ${ }^{32}$.

\section{Wizerunek Jeleny Andegaweńskiej w hagiografii i hymnografii}

W świetle przytoczonych powyżej faktów należy więc założyć, że na kształt literackiego wizerunku królowej, wykreowanego przez Danila II, miało wpływ wiele czynników pozaartystycznych. Arcybiskup z całą pewnością brał pod uwagę wymogi ówczesnej sytuacji polityczno-religijnej na Bałkanach, nakazującej możliwie szybkie doprowadzenie do kanonizacji Andegawenki. Nie sposób nie zauważyć, że powstający pod jego piórem obraz zawiera również wiele elementów, zdradzających osobistą fascynację autora. W efekcie mamy tu do czynienia z portretem znacznie wyidealizowanym. Danilo przemilcza kilka kłopotliwych szczegółów z biografii Jeleny (m.in. kwestię jej kontaktów dyplomatycznych z Dubrownikiem), nad innymi przemykając się z godną podziwu zręcznością. Dla przykładu: w żywocie królowej oraz w utworze poświęconym osobie jej męża wspomina - co prawda - o cudzoziemskim pochodzeniu swej bohaterki, pisząc, iż wywodziła się z francuskiego rodu ( племена фрушкога), zaraz jednak śpieszy wyjaśnić, że była córką sławnych i bogatych rodziców (кћи славних родитеља, који су били у великом богатству и славu). Nie nadmienia przy tym ani słowem o powiązaniach Jeleny z królewskim rodem Andegawenów, ograniczając się do określenia jej statusu społecznego tyleż zaszczytnym, co wieloznacznym terminem „carski” (од царскога племена) $)^{33}$.

\section{Jelena jako żona i matka}

Nie ulega wątpliwości, że w średniowiecznej Serbii - podobnie jak w innych tradycyjnych społeczeństwach - za najważniejszy wyznacznik pozycji kobiety uznawano jej sytuację osobistą i rodzinną. Również Danilo II, koncentrując się głównie na publicznej działalności Jeleny, na pierwszych stronach poświęconych jej osobie utworów, podąża krok w krok za obowiązującą w jego epoce konwencją: w Żywocie królowej Jeleny, zaraz po krótkiej sekwencji, dotyczącej rodziców i pochodzenia bo-

\footnotetext{
32 Dar stowa. Ze starej literatury serbskiej..., s. 234; М. Кашанин, op. cit., s. 257, 259.

33 Данило II, Житије краљьие Јелене (dalej: ЖКЈ), [in:] Стара српска књижевност, ed. C. Томин, Сремски Карловци - Нови Сад 2001, s. 207; idem, Живот благочастивога краља Уроша званога Велики (dalej: ЖКУ), [in:] Животи краљева и архиепископа српских од архиепископа Данила II, ed. Л. Мирковић, Н. Радојчић, Београд 1935, s. 10.
} 
haterki, wspomina o jej małżeństwie z władcą Serbii, określając ich pożycie mianem „sławnego i wspaniałego" (славно и дивно $)^{34}$.

W biografii Urosza I odnajdujemy natomiast obraz o wiele bardziej rozbudowany i nasycony odwołaniami do Starego i Nowego Testamentu. Jelena miała żyć wraz ze swym mężem w przykładnym związku, opartym na poszanowaniu religijnych przykazań i nakazów, wypełnionym modlitwą i bojaźnią Bożą. Interesujące, że na kartach tego utworu Danilo posuwa się do stwierdzenia, iż Urosz otrzymał swą małżonkę wprost od Boga (са Богом дарованом му супругом). Ani słowem nie wspomina natomiast o politycznych pertraktacjach, które z natury rzeczy poprzedzać musiały ślub króla Serbii z krewniaczką Ludwika IX ${ }^{35}$.

W podobnie podniosłej, nieomal mistycznej, optyce ukazuje arcybiskup przełomowe w dziejach związku Jeleny i Urosza wydarzenie, tj. narodziny ich pierworodnego syna, Stefana Dragutina. Serbska królowa miała, według niego, zajść w ciążę w sposób „niepokalany”, za sprawą Ducha Świętego, podobnie jak Bogurodzica, matka starotestamentowego proroka Samuela, Anna - rodzicielka Marii, matki Jezusa, żona Abrahama - Sara i Elżbieta - matka Jana Chrzciciela ${ }^{36}$.

Andegawenka jest w oczach serbskiego duchownego nie tylko ideałem chrześcijańskiej małżonki, ale również wspaniałą matką, nieustannie zatroskaną o los swych dzieci. „O miłości serdeczna, o boleści matczyna! Patrz, jak się ona modli za synów swoich" ${ }^{37}$ - stwierdza z zachwytem Danilo w żywocie św. Jeleny, a w dalszej partii utworu, opisującej wydarzenia związane ze śmiercią i pogrzebem swej bohaterki, wkłada w usta Stefana Milutina słowa, wskazujące ewidentnie na fakt, że władca ten zawdzięczał prawdziwie chrześcijańskie wychowanie i staranną edukację wyłącznie swojej matce ${ }^{38}$.

O wiele istotniejszą kwestią zdaje się być, wielokrotnie podkreślany w przekazie Danila II, niekwestionowany autorytet i olbrzymi wpływ Jeleny na polityczne decyzje obu jej synów, dostrzegalny także w okresie ich dojrzałości. Z Żywotu króla Milutina dowiadujemy się, że Andegawenka pełniła funkcję doradcy u boku swego syna, Stefana Urosza II (договоривши се са светом и блаженом матером својом $)^{39}$, z biografii arcybiskupa Joanikija natomiast - że brała udział w ważnych uroczystościach państwowych i cerkiewnych, takich jak np. przeniesienie relikwii tego dostojnika do monasteru w Sopocianach ${ }^{40}$. Co więcej, arcybiskup podkreśla również wielokrotnie, iż

34 ЖКЈ, s. 208.

35 ЖКУ, s. 10.

36 ЖКУ, s. 11-12.

37 „О љубави срдачна, о болезни материнска, види како се моли за синове своје”. ЖКЈ, s. 214. Tłumaczenie polskie: Arcybiskup Danilo II, Żywot świętej Jeleny (dalej: ŻJ), [in:] Dar stowa. Ze starej literatury serbskiej..., s. 86.

38 ЖКJ, s. 225-226.

39 Данило II, Месеиа октобра 29. дан, житија и дела благочастивога и христољубивога и светороднога, моћнога и самодржавнога са Богом господина краља Стефана Урома (daleј: ЖКМ), [in:] Животи краљева и архиепископа српских..., s. 113.

${ }^{40}$ Idem, Јоаникије архиепископ српски, [in:] ibidem, s. 219-220. 
Jelena nieustannie pouczała swoich synów o obowiązkach monarchy, przestrzegając ich zwłaszcza przed niebezpieczeństwem popadnięcia we wzajemną niezgodę i wrogość, mogącą wywrzeć fatalny wpływ na kondycję państwa serbskiego ${ }^{41}$.

W tym kontekście niezwykle ciekawy musi się okazać opis sceny, która rozegrała się najprawdopodobniej w 1276 r., krótko po zamachu stanu, dokonanym przez Stefana Dragutina. Warto tu odnotować, iż Danilo przemilcza rolę, jaką odegrała Jelena w pozbawieniu tronu własnego męża. Kreśli natomiast barwny obraz decydującej rozmowy Andegawenki z jej najstarszym dzieckiem. Zarówno w żywocie Urosza I, jak i w utworze poświęconym jego synowi czytamy, iż Dragutin powitał matkę z niezwykłą wprost czołobitnością: ,przyjął ją z wielką czcią i sławą, i oddał jej należną cześć" ${ }^{\prime 2}$. Następnie młody król jasno dał do zrozumienia, że spór, który stoczył z ojcem, nie dotyczy jej osoby. I tu rzecz ciekawa - Danilo nadmienia, co prawda, o umowie zawartej między Jeleną i Stefanem Dragutinem, na mocy której Andegawenka otrzymała od syna odrębną dzielnicę do samodzielnego władania, niemniej jednak szczegóły tej stricte politycznej gry ukazuje w klimacie wzruszającej wymiany zdań między matką i jej pierworodnym dzieckiem. Słyszymy więc, iż początkowo Dragutin wyraził nawet gotowość oddania swej rodzicielce rządów nad całym państwem, by - niejako naturalną koleją rzeczy - otrzymać je ponownie z jej ręki. Wielokrotnie zapewniał ją też o swym oddaniu i posłuszeństwie: „będę tobie posłuszny i służyć ci będę ze strachem i miłością w wierze prawdziwej i uczynię ci jeszcze większy szacunek i sławę, żeby przez ciebie spoczęła na mnie pełnia Bożego błogosławieństwa"43. Królewska matka staje się, więc, w tym kontekście swoistą pośredniczką między władcą a Bogiem. Od konstatacji tego typu już tylko krok do uznania Jeleny za opiekunkę państwa serbskiego i zwornik, łączący rodzinę panującą ze sferą sacrum. Sugestie tego typu zdają się zawierać ostatnie strofy żywotu omawianej władczyni, ukazujące płacz Stefana Dragutina i Stefana Milutina nad grobem matki, na tle powszechnej, ogólnonarodowej żałoby ${ }^{44}$.

\section{Jelena jako ideal chrześcijańskiej władczyni}

Jakkolwiek nie wysławiałby Danilo uczuć, łączących Jelenę z mężem i dziećmi, nie sposób nie zauważyć, iż jest ona w jego oczach przede wszystkim królową Serbii. Literacki wizerunek Andegawenki, powstający pod piórem arcybiskupa, musi być zatem analizowany głównie jako portret monarchini, panegiryk, ukształtowany w zgodzie z bizantyńską tradycją wysławiania władców, z której Danilo zdaje się czerpać pełnymi garściami. I tak, wpływ charakterystycznego dla piśmiennictwa wschodnio-

\footnotetext{
41 ЖКЈ, s. 214.

${ }^{42}$ Arcybiskup Danilo II, Żywot świętego Stefana Dragutina (dalej: ŻSD), [in:] Dar słowa. Ze starej literatury serbskiej..., s. 100; ЖКУ, s. 18.

43 ŻSD, s. 101.

44 ЖКJ, s. 225-227.
} 
chrześcijańskiego gatunku literackiego - pochwały cesarza (enkomionu, logos basilikos $)^{45}$ można dostrzec w treści Żywotu królowej Jeleny chociażby w odwołaniach do rozpowszechnionego nad Bosforem przekonania o Boskim pochodzeniu władzy monarszej, implikującym niejako sakralny status panującego. Dla przykładu: w końcowej partii omawianego utworu Danilo wkłada w usta umierającej Jeleny modlitwę za pomyślność „darowanego jej przez Boga państwa” (државу отачаства мога, даровану ми Тобом $)^{46}$. W innym punkcie narracji porównuje natomiast postać Andegawenki - znów w zgodzie z bizantyńską tradycją - do świecznika, danego Serbom przez Króla Niebieskiego ku ogólnemu pożytkowi narodu (од Господа даровани светилник отачаству своме $)^{47}$.

W nawiązaniu do wschodniorzymskiej konwencji rozwija również arcybiskup opowieść o osobistych przymiotach opisywanej przez siebie władczyni. Za cechy charakteru, które zasługują na szczególne upamiętnienie, uznaje więc przede wszystkim cnoty teogonalne: pobożność (gr. eusebeia, scs. благочестие) i bojaźń Bożą ${ }^{48}$, manifestujące się jednak nie tylko w aktach osobistej religijności (modlitwa, asceza) ${ }^{49}$, ale również w szeroko zakrojonej działalności dobroczynnej i fundacyjnej. O tym ostatnim aspekcie aktywności królowej pisze Danilo dużo i chętnie. Podobnie jak wielu innych twórców z obszaru Slavia Orthodoxa ${ }^{50}$ podkreśla szacunek i współczucie monarchini, okazywane osobom niskiego pochodzenia, wspomina o rozdawaniu przez nią jałmużny potrzebującym (ubogim, niepełnosprawnym, obcokrajowcom, sierotom i wdowom), a także o postępowaniu w ślad za ewangelicznym nakazem ,głodnych nakarmić, nagich przyodziać, bezdomnych w dom przyjąć"51. Wspomina też o opiece, jaką Jelena miała ponoć w zwyczaju świadczyć chorym osobiście ${ }^{52}$.

Monarsza szczodrobliwość Andegawenki przejawiała się - według Danila II - nie tylko we wsparciu, okazywanym najuboższym, ale również w hojności wobec cerkwi i monasterów, rozsianych po terytorium państwa serbskiego. Jelena miała nie szczędzić środków na wyposażenie istniejących świątyń w księgi, ikony i naczynia liturgiczne $^{53}$.

45 T. Wnętrzak, Konstantyn Wielki w oczach Euzebiusza z Cezarei i w badaniach wspótczesnych historyków, [in:] Euzebiusz z Cezarei, Życie Konstantyna, tłum. eadem, Kraków 2007, s. 60-61.

46 ЖКJ, s. 224.

47 ЖКЈ, s. 220.

48 T. Wnętrzak, op. cit., s. 77-78.

49 ЖКЈ, s. 208, 210, 213, 222.

${ }^{50}$ Literacki wizerunek Jeleny Andegaweńskiej warto zestawić chociażby z portretami świętych władców Rusi Kijowskiej - Olgi i Włodzimierza. W poświęconych ich osobom zabytkach piśmiennictwa staroruskiego z XI-XII w. zwraca bowiem na siebie uwagę niezwykle silne zaakcentowanie cnoty miłosierdzia oraz działalności dobroczynnej. Można również nadmienić, iż podobne przymioty przypisywano też wielu cesarzom i cesarzowym w Bizancjum.

51 „љубећи ниште, и дајући милостињу странима, одевајући наге, и уводећи у дом бескућнике (...) довољно милостиње дајући свакоме који је требао, насићујући гладне утробе”. ЖКЈ, s. 210$-211,213,215$.

52 ЖКJ, s. 215-216.

53 „трудила се о томе како ће давати милостиње у божаствене храмове и све што је на потребу, стављајући божаствене књиге у своме дому, а исто тако и свештене сасуде, златне и сребрне, укра- 
Niemniej szczegółowo opisuje arcybiskup starania Andegawenki wokół budowy monasteru Gradac. W Żywocie królowej Jeleny czytamy, że postanowiwszy założyć wzorem wielu świętych mężów - na chwałę Bożą i pamiątkę własnych czynów, prawosławną wspólnotę klasztorna, królowa ta osobiście nadzorowała prace budowlane, a także wybierała artystów i rzemieślników, zdatnych do wszelkiego rodzaju robót ${ }^{54}$. Po ich zakończeniu zatroszczyła się natomiast o wyposażenie swej fundacji m.in. w bogato zdobione ikony, relikwie świętych (moszczi), księgi i naczynia liturgiczne ${ }^{55}$.

Co więcej, wykorzystując swoje uprawnienia prawodawcze, zadbała Jelena zarówno o nadanie nowo wzniesionemu monasterowi odpowiedniej reguły (podobno własnoręcznie spisała dla niego typikon, który niestety nie zachował się do naszych dni), jak i o zabezpieczenie środków na utrzymanie wspólnoty - Danilo wspomina o chryzobulli, zaopatrzonej w osobisty podpis władczyni, darowującej klasztorowi Gradac niemałe włości ziemskie ${ }^{56}$. Andegawenka pokusiła się również o odpowiedni dobór mnichów do założonego przez siebie monasteru oraz naznaczenie pewnej ilości diakonów, zarządzających majątkiem wspólnoty ${ }^{57}$.

W tym miejscu warto postawić pytanie o stosunek arcybiskupa do przynależności konfesyjnej Jeleny. Czytając o fundacjach królowej czy o przywdzianiu przez nią szaty mniszej można bowiem zauważyć, iż autor jej żywotu nie określa wprost obrządku, z jakim czuła się związana. Co więcej, stara się przekonać odbiorcę swych utworów o wierności Andegawenki wobec prawosławia, pisząc np. o utrzymywaniu przez nią kontaktów korespondencyjnych jedynie $\mathrm{z}$ autorytetami chrześcijaństwa wschodniego - „ojcami duchowymi” w Jerozolimie, w klasztorze na Synaju czy na świętej górze Athos (z całkowitym pominięciem papieża rzymskiego) ${ }^{58}$. Polska badaczka słowiańskich literatur średniowiecznych, Izabela Lis-Wielgosz postawiła ostatnio interesującą teze, jakoby zawoalowaną wzmiankę na temat katolickiego wyznania Jeleny można było odnaleźć w scenie śmierci królowej, zamieszczonej w omawianym przez nas zabytku. Zapis ostatnich chwil żony Urosza I różni się bowiem znacznie od innych ujęć tematu mortis, spotykanych w piśmiennictwie staroserbskim. Nie odnajdujemy tu wizji spokojnego, a poniekąd nawet radosnego, konania osoby głęboko przekonanej o wartości Bożego miłosierdzia i czekających tuż za progiem śmierci rozkoszach rajskich, tak zadziwiającej współczesnego czytelnika w żywotach Stefana Nemanji czy św. Sawy. Stykamy się natomiast z dramatycznym opisem oczekiwania na kres,

шене бисером и скупоценим камењем, изабране одежде јерејима и сваке црквене правде што је на потребу". ЖКЈ, s. 213.

54 ЖКЈ, s. 216-217.

55 „изпуни овај дом пресвете сваким изобиљем, наиме божаственим књигама и свештеним сасудима златним и сребрним, украшеним драгоценим камењем и другим лепотама. Иконе оковане златом пуне моштију светих, златоткане завесе и друге црквене потребе дарова да се не може исказати”. ЖКЈ, s. 219.

56 „приходе и села многа изабрана приложи том светом месту, утврдивши хрисовуље са својим потписом”. ЖКЈ, s. 219.

57 Loc. cit.

58 ЖКJ, s. 211. 
pełnym przerażających obrazów mąk piekielnych - Jelena na łożu śmierci jest świadoma swoich grzechów i „błędów młodości”, nie żywi zatem nadziei na zbawienie, odchodzi pogrążona w strachu i zwątpieniu ${ }^{59}$. Dla XIV-wiecznego odbiorcy aluzja to aż nadto czytelna: w ten sposób nie może konać prawowierna władczyni, już za życia będąca swoistą ikoną Boga na ziemi, lecz - nawrócona tuż przed śmiercią katoliczka, przeświadczona o konieczności odpokutowania swoich przewin. Grzechów, które zaznaczmy to raz jeszcze - nie przeszkodzą jej bynajmniej w uzyskaniu statusu świętej Serbskiej Cerkwi Prawosławnej zaledwie w kilka lat później.

W żywocie królowej pomieszczona została również obszerna sekwencja, zawierająca uwypuklenie tych spośród wielu jej zalet, które powiązać można z monarszym virtus. Danilo charakteryzuje Andegawenkę jako osobę w harmonijny sposób łączącą w sobie wrodzoną dobroć i łagodność charakteru z umiejętnością śmiałego wygłaszania sądów i ferowania sprawiedliwych wyroków (омтра речjy, а блага nо природи (...) у заповедағу кротка) ${ }^{60}$. Chwali też jej szczere i pozbawione wyrachowania nastawienie do ludzi, tak jaskrawo kontrastujące z postępowaniem wielu jej współczesnych (не нађе се у њој лицемерност, као што је има у неких) ${ }^{61}$. Na szczególną uwagę zasługuje tu również opis zachowania Jeleny względem swych poddanych, charakteryzującego się zgoła niespotykanym w tamtych czasach demokratyzmem i egalitaryzmem. Jeśli wierzyć arcybiskupowi, królowa potrafiła docenić każdy mądry osąd, niezależnie od statusu społecznego tego, kto go wypowiadał, żadnej przedstawionej jej kwestii nie pozostawiała bez odpowiedzi, odnosząc się z jednakowym szacunkiem do wszystkich mieszkańców swego państwa, bez względu na stan majątkowy, przynależność stanową czy wyznanie ${ }^{62}$.

Elementem, któremu poświęca Danilo relatywnie sporo miejsca, jest z całą pewnością ponadprzeciętne wykształcenie Andegawenki, połączone z niekłamanym umiłowaniem wiedzy i pewnymi inklinacjami literackimi. Z Żywotu królowej Jeleny czerpiemy informację o jej niezwykłym oczytaniu (познавајући све књиге) ${ }^{63}$, jak też praktyce utrzymywania stałej korespondencji z największymi autorytetami świata wschodniego ${ }^{64}$. Dzięki rzetelności arcybiskupa możemy nawet zapoznać się z treścią jednej z tych, prowadzonych listownie, dysput: postarał się on bowiem o zilustrowanie swego wywodu fragmentem pisma, wysłanego przez Jelenę na świętą górę Athos wraz z załączoną odpowiedzią mnichów ${ }^{65}$.

$\mathrm{Z}$ intelektualnymi aspiracjami Jeleny wiąże się jeszcze jedno dokonanie, bardzo chętnie przywoływane we współczesnej historiografii, zwłaszcza zaś w opracowaniach, powstających w ramach nurtu gender studies, tj. zorganizowanie przez

\footnotetext{
${ }^{59}$ I. Lis, Śmierć w literaturze staroserbskiej (XII-XIV w.), Poznań 2003, s. 43, 46-48, 108,115.

60 ЖКJ, s. 209.

${ }^{61}$ Loc. cit.

62 „великога и малога, богата и ништа, праведника и грешника, болна и здрава, свакога од њих једнако је поштовала и свакоме дужну част одавала”. ЖКЈ, s. 209.

${ }^{63}$ Loc. cit.

64 ЖКЈ, s. 211.

65 ЖКЈ, s. 211-212.
} 
Andegawenkę przy monarszym dworze w miejscowości Brniaci (Брњаци) pierwszej w dziejach szkolnictwa na ziemiach serbskich szkoły dla dziewcząt ${ }^{66}$. Danilo opisuje tę inicjatywę dość dokładnie. Wspomina, że królowa rozkazała zebrać w swym pałacu wszystkie osierocone dziewczyny z poddanego jej władzy obszaru, a następnie uczyć je wszelkich pożytecznych rzeczy „odpowiednich dla kobiet”, m.in. robót ręcznych. Podkreśla również, że po osiagnięciu pełnoletniości panny te były przez swą opiekunkę wydawane za mąż i zaopatrywane w posag ${ }^{67}$.

Na zakończenie wypada jednak podkreślić, iż Jelena jawi się w świetle przekazu Danila nie tylko jako wyczulona na ludzką niedolę osoba, lecz również - świadoma swych obowiązków wobec państwa i narodu władczyni, zatroskana o jego dalszy los. Postawa ta uzewnętrznia się najsilniej w końcowej partii Żywotu królowej Jeleny, zawierającej obszerny opis śmierci Andegawenki. Arcybiskup - naoczny świadek ostatnich chwil monarchini - informuje nas, iż na łożu śmierci Jelena modliła się przede wszystkim o pomyślność państwa serbskiego i wszystkich jego mieszkańców $^{68}$, antycypując tym samym rolę, która została jej przydzielona zaraz po kanonizacji - opiekunki monarchii Nemaniczów, wypraszającej nieustannie u Boga łaskę dla „serbskiej ziemi”. Блажена си, јер се твојим молитвана утврђују државе благоверних краљьева српске земье - konkluduje Danilo II w jednym z ostatnich akapitów żywotu świętej ${ }^{69}$.

\title{
THE LATIN QUEEN ON THE THRONE OF 13TH CENTURY SERBIA. THE IMAGE OF HELENE D'ANJOU IN THE WRITINGS OF ARCHBISHOP DANILO II
}

\author{
Summary
}

The main purpose of this article is to present one of the most interesting women in the history of medieval Serbia - Helene d'Anjou (Jelena Anžujska), the wife of the king Stefan Uroš I and the mother of Stefan Dragutin and Stefan Milutin. Queen Jelena's origin has so far not been established with certainty. She is supposed to be the daughter of Raoul de Courtenay, the cousin of Louis IX of France, Charles d'Anjou, king of Naples and Baldwin, emperor of Constantinople after the Latin conquest. It is also important to confirm that she was a Catholic. The most reliable source of information about her life is the biography written by Danilo II, archbishop of the Serbian Orthodox Church. This is the only life of a woman that he wrote and is particularly valuable because Danilo knew Jelena personally and clearly liked and admired her.

66 Ж. Фејфрић, op. cit.; С. Hawhesworth, op. cit., s. 68-69; М. Кашанин, op. cit., s. 23.

67 „заповеди у целој својој области сабирати кћери сиротих родитеља, и њих хранећи у своме дому, обучаваше сваком добром реду и ручном раду који приличи за женски пол”. ЖКЈ, s. 213.

68 ЖКJ, s. 224-225.

69 ЖКЈ, s. 226. 
